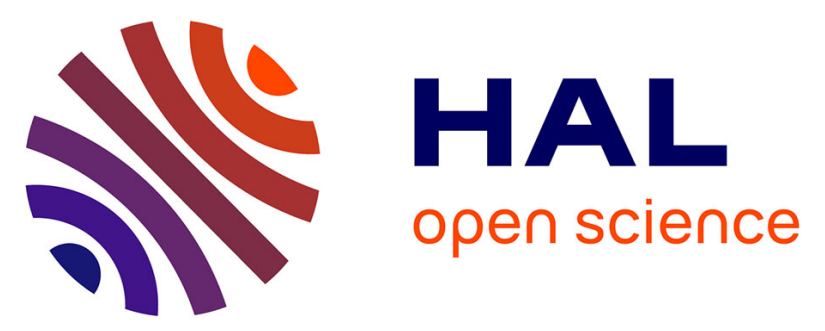

\title{
Evaluation of greenhouse gas emissions and design of mitigation options: a whole farm approach based on farm management data and mechanistic models
}

Jean-Louis Fiorelli, Jean-Louis Drouet, Sylvia Duretz, Benoit Gabrielle, Anne-Isabelle Graux, Vincent Blanfort, M. Capitaine, Pierre Cellier, Jean-François Soussana

\section{To cite this version:}

Jean-Louis Fiorelli, Jean-Louis Drouet, Sylvia Duretz, Benoit Gabrielle, Anne-Isabelle Graux, et al.. Evaluation of greenhouse gas emissions and design of mitigation options: a whole farm approach based on farm management data and mechanistic models. International Journal of Sustainable Development, 2014, 17 (1), pp.22-34. 10.1504/IJSD.2014.058432 . hal-01192465

\section{HAL Id: hal-01192465 \\ https://hal.science/hal-01192465}

Submitted on 27 May 2020

HAL is a multi-disciplinary open access archive for the deposit and dissemination of scientific research documents, whether they are published or not. The documents may come from teaching and research institutions in France or abroad, or from public or private research centers.
L'archive ouverte pluridisciplinaire HAL, est destinée au dépôt et à la diffusion de documents scientifiques de niveau recherche, publiés ou non, émanant des établissements d'enseignement et de recherche français ou étrangers, des laboratoires publics ou privés. 


\title{
Evaluation of greenhouse gas emissions and design of mitigation options: a whole farm approach based on farm management data and mechanistic models
}

\author{
Jean-Louis Fiorelli* \\ INRA SAD Mirecourt, 662 Av Louis Buffet, \\ Mirecourt, 88500, France \\ E-mail: fiorelli@mirecourt.inra.fr \\ *Corresponding author \\ Jean-Louis Drouet, Sylvia Duretz and \\ Benoît Gabrielle \\ UMR INRA AgroParisTech EGC, \\ BP1, 78850, Thiverval-Grignon, France \\ E-mail: drouet@grignon.inra.fr \\ E-mail: Benoit.Gabrielle@agroparistech.fr \\ E-mail: sylvia.duretz@gmail.com
}

\section{Anne-Isabelle Graux \\ INRA UREP, 234 Av. du Brezet,}

Clermont-Ferrand Cedex 02, 63039, France

E-mail: anne-isabelle.graux@clermont.inra.fr

\section{Vincent Blanfort}

CIRAD, INRA UREP, 234 Av. du Brezet, Clermont-Ferrand Cedex 02, 63039, France E-mail: blanfort@cirad.fr

\section{Mathieu Capitaine}

ENITA AFOS, Marmilhat BP 35,

Lempdes, 63370, France

E-mail: mathieu.capitaine@vetagro-sup.fr

\section{Pierre Cellier}

UMR INRA AgroParisTech EGC, BP1, 78850, Thiverval-Grignon, France

E-mail: cellier@grignon.inra.fr 


\title{
Jean-François Soussana
}

\author{
INRA UREP, 234 Av. du Brezet, \\ Clermont-Ferrand Cedex 02, 63039, France \\ E-mail: jean-françois.soussana@paris.inra.fr
}

\begin{abstract}
Agricultural activities are important sources of nitrous oxide $\left(\mathrm{N}_{2} \mathrm{O}\right)$, methane $\left(\mathrm{CH}_{4}\right)$ and carbon dioxide $\left(\mathrm{CO}_{2}\right)$. They contribute approximately $10 \%$ of the total emitted greenhouse gases $(\mathrm{GhG})$ in the European Union. We search for evaluating GhG emissions at the farm level and designing mitigation options. As emissions occur at many stages within the farm operation, it is crucial to consider nutrient cycling and farm working. Our proposal comprises three characteristics: an integrated farm approach which combines empirical and mechanistic modelling through describing $\mathrm{C}$ and $\mathrm{N}$ fluxes through two coupled models of land use: a farmers' practices description; and system boundaries limited to the farm gate, but including also pre- and post-chain effects. We used a case study located in semi-continental conditions (Mirecourt - North-Eastern France). The simulated farming system is a mixed dairy and crops system so as to account for a rather generic farming system.
\end{abstract}

Keywords: greenhouse gas emissions; farm management practices; mixed crop livestock systems; modelling; whole farm approach.

Reference to this paper should be made as follows: Fiorelli, J-L., Drouet, J-L., Duretz, S., Gabrielle, B., Graux, A-I., Blanfort, V., Capitaine, M., Cellier, P. and Soussana, J-F. (2014) 'Evaluation of greenhouse gas emissions and design of mitigation options: a whole farm approach based on farm management data and mechanistic models', Int. J. Sustainable Development, Vol. 17, No. 1, pp.22-34.

Biographical notes: Jean-Louis Fiorelli (Research Engineer, $\mathrm{PhD}$ ) is the leader of the team 'Design and assesment of sustainable farming systems' of ASTER Unit (Mirecourt, France). He is working on modelling biomass flows and nutrient management of organic mixed crop-dairy systems.

Jean-Louis Drouet is a Senior Scientist in Environment \& Fields Crops unit located in Grignon near Paris. He contributes to modelling approaches to assess the impacts of agricultural practices and other technical decisions as regards the quality of environmental compartments and the modification of plant covers.

Sylvia Duretz closed successfully her PhD training about this modelling project.

Benoît Gabrielle is a Senior Scientist in Environment \& Fields Crops unit located in Grignon near Paris. He contributes to modelling approaches to assess the impacts of agricultural practices and other technical decisions as regards the quality of environmental compartments and the modification of plant covers.

Anne-Isabelle Graux closed successfully her PhD training about this modelling project.

Vincent Blanfort is a Senior Agronomist from Grassland Ecosystem unit located in Clermont-Ferrand.

Matthieu Capitaine is an Assistant Professor in VetAgro Sup, an engineer high school located in Clermont-Ferrand. 
Pierre Cellier is a Senior Scientist in Environment \& Fields Crops unit located in Grignon near Paris. He contributes to modelling approaches to assess the impacts of agricultural practices and other technical decisions as regards the quality of environmental compartments and the modification of plant covers.

Jean-François Soussana is a Senior Agronomist from Grassland Ecosystem unit located in Clermont-Ferrand. He is presently the head of researches in environment in the French Agronomic Research Institute and was IPCC expert in 2007.

This paper is a revised and expanded version of a paper entitled 'Evaluating the greenhouse gas emissions and designing mitigation options: a whole farm approach based on farm management practices data coupled with crop and grassland mechanistic models' presented at Workshop 5 held during the 8th European IFSA Symposium 'Empowerment of the Rural Actors: A Renewal of Farming Systems Perspectives', Clermont-Ferrand, France, 6-10 July 2008.

\section{Introduction}

Agricultural activities are important sources of atmospheric nitrous oxide $\left(\mathrm{N}_{2} \mathrm{O}\right)$, methane $\left(\mathrm{CH}_{4}\right)$ and carbon dioxide $\left(\mathrm{CO}_{2}\right)$. In the European Union, the sector agriculture contributes $9 \%$ to total EU-15 greenhouse gas $(\mathrm{GhG})$ emissions, making it the second largest sector after energy. The most important GhGs from sector agriculture are $\mathrm{N}_{2} \mathrm{O}$ and $\mathrm{CH}_{4}$ accounting for $5 \%$ and $4 \%$ of the total GhG emissions respectively (EEA, 2007).

The emissions from agriculture decreased by $11 \%$ from $434 \mathrm{Tg}$ in 1990 to $386 \mathrm{Tg}$ in 2005. Large reductions occurred in the largest key sources $\mathrm{CH}_{4}$ from cattle and $\mathrm{N}_{2} \mathrm{O}$ from direct soil emissions. The main reasons are the declining cattle numbers and a decreasing use of fertiliser and manure in most Member States rather than specific GhG policies. With indirect emissions $\left(\mathrm{N}_{2} \mathrm{O}\right)$, these three key sources account for about $70 \%$ of agricultural GhG emissions of the EU-15 (EEA, 2007).

In contrast to industry, the emissions from agriculture are not confined to relatively few large emitters, but are diffusely spread across Europe. On each individual farm, the farmer is responsible for the actions taken to work its farming system. As farmers' goals may be rather different considering historic and geographical conditions, farmer practices are themselves more or less different and frequently require an individual approach, especially to assess and eventually change the workings of the farm system.

Research has focused on identifying the sources, studying the biotic and abiotic processes (Freibauer, 2003; Soussana et al., 2007) and reviewing mitigation options either to reduce GhG emissions (Weiske et al., 2006) or to sequester carbon in the soil (Soussana et al., 2004; Smith, 2004).

Since agricultural management is one of the key drivers of $\mathrm{C}$-sequestration and emission, but also of limiting $\mathrm{N}_{2} \mathrm{O}$ and $\mathrm{CH}_{4}$ emissions from grassland, cropland and animal production, there is potential to reduce the net GhG balance. However, management choices may lead to major trade-offs between processes, especially when you consider mixed farming systems combining crop and animal production as in many European ruminant livestock systems. Moreover, the structure of the GhG reporting framework (IPCC, 1997) has not encouraged the taking of an integrated farm system approach. Since management decisions are really made at the farm level, the assessment 
of emissions and the design of mitigation options had to be done through a farm level full accounting approach that includes farmer's practices.

Some proposals exist about the farm level approach for mitigating GhG emissions from ruminant livestock systems. Schils et al. (2006a) proposed a general framework considering the definition of two essential farm compartments, through the utilisation of home-grown roughage by animals on one hand and the return of excreta to the soil-crop system on the other one. The development of whole farm approaches has been taken up by several other research groups in Europe, and some models were used to this end such as DairyWise (Van Alem and Van Scheppingen, 1993; Schils et al., 2005), FarmGHG

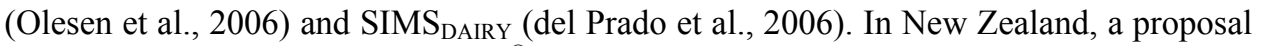
was made to use the OVERSEER ${ }^{\circledR}$ nutrient budget model to estimate on-farm GhG emissions (Wheeler et al., 2008). For our own purpose, we seek to use another model, FarmSim (Salètes et al., 2004) initiated some years ago during a European research project (GREENGRASS, EVK2-CT2001-00105).

This paper presents some recent advances by our research group, extending the previous characteristics of the FarmSim model through a best accounting of croplands emissions. We outline the main principles of our approach, then the characteristics of the mixed crop livestock farm on which the model was setup before discussing the working of the model, results and the perspectives we have to improve FarmSim model.

\section{Model description}

\subsection{A whole farm approach}

A crop livestock farm is simultaneously a management unit where decisions are made to implement practices and a production unit where fields, animals, buildings, machinery and stores contribute to its environmental balance generating energy and matter flows including GhG. These flows are closely interconnected and their coherence can only be understood at the farm level.

Figure 1 Carbon (C) and Nitrogen (N) flows from a whole mixed crop livestock farm approach

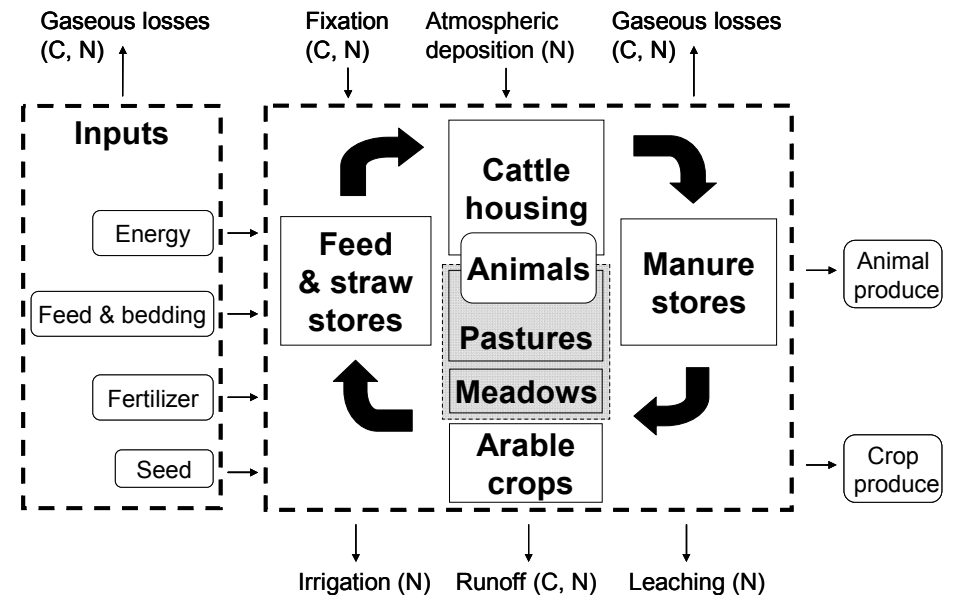


The emissions of GhG are related to carbon and nitrogen flows and environmental conditions. Here, we will consider carbon and nitrogen cycling through a whole farm system approach (Figure 1) in order to quantify and assess the main processes that lead to GhG release or uptake by the farm and to simulate the resulting farm GhG balance.

The interactions between the different flows are especially strong in the mixed crop livestock farms with ruminants: a large part of effluents are recycled on to the fields to contribute to home-grown fodder, feeds and straw 'supply for animals' bedding. Moreover, the farm operation relies on the purchase of a variety of inputs (fertilisers, feedstuffs, electricity and fuel...), the production and transport of which also require energy and emit GhG. Taking account of the life cycle of products used on the farm and brought in from outside is necessary to gain a full picture of the true balance and this requires knowledge of the value chain processes and flows.

\subsection{A semi-mechanistic model}

FarmSim has been first designed to describe the above and below ground $\mathrm{C}$ and $\mathrm{N}$ fluxes in cattle farms, and calculate the net balance of GhG emissions (Salètes et al., 2004) through a consistent description of the farm features and practices both including grazing animals.

In the first release, it only involved a strong connection to the pasture simulation model PaSim, the grassland model originating from the Hurley Pasture model (Thornley, 1998) to simulate grasslands emissions. All the other emissions were calculated using IPCC methodology (Tier 2) with emission factors.

PaSim is a model operating at the field scale originally developed to simulate dry matter production and associated flows of carbon, nitrogen and water in productive pastures (Riedo et al., 1998, 2000). It was extended by Schmid et al. (2001) with respect to the production and diffusion of $\mathrm{N}_{2} \mathrm{O}$, then by Vuichard et al. (2007) concerning water stress, senescence, detrimental impact of trampling and excreta by grazing animals on vegetation and effects of diet quality on the emissions of methane from grazing animals. Its target ecosystem is essentially a mixed sward, with grasses and legumes co-existing in fixed proportions. PaSim calculates the growth and senescence of aboveground vegetation biomass accounting for sporadic removals when the grassland is cut and for continuous removals when it is grazed. Limitations induced by high leaf area index (LAI), soil water deficits and aging of leaves are also included. This model allows for a fully dynamic calculation of fluxes of carbon dioxide $\left(\mathrm{CO}_{2}\right)$, nitrous oxide $\left(\mathrm{N}_{2} \mathrm{O}\right)$ and methane $\left(\mathrm{CH}_{4}\right)$ in the grasslands.

The FarmSim model is a simulation framework allowing the description in a consistent way of the characteristics of a mixed crop ruminant farm and to calculate the inherent emissions. The model is structured into nine modules (Figure 2), requiring detailed data inputs on the farm structure, meteorological conditions, soils, animals, grassland and cropland management, but also animal winterfeeding strategy, waste production system and imported resources.

Whilst GhG emissions from grasslands are always calculated by PaSim model, the emissions from croplands are now calculated by the CERES-EGC model: This latter model is based on CERES (Jones and Kiniry, 1986), a mechanistic fully dynamic model modified to suit French conditions (Gabrielle et al., 1998). CERES simulates the dynamic of water, carbon and nitrogen in soil-crop systems. It runs on a daily time step and is available for a large range of crop species. It runs from standard weather data. CERES 
comprises three main sub-models. First, a physical module simulates the transfer of heat, water and nitrate down the soil profile, as well as soil evaporation, plant water uptake and transpiration in relation to climatic demand. Next, a microbiological module simulates the turnover of organic matter in the plough layer, involving both mineralisation and immobilisation of inorganic N. In CERES-EGC, the NCSOIL model (Molina et al., 1983) was substituted for the original CERES module, and comprises three endogenous soil OM pools: microbial biomass, active humus ('humads') and passive humus. The third module simulates crop growth and development. Photosynthates are partitioned on a daily basis to currently growing organs (roots, leaves, stems, fruits) according to the crop development stage. The latter is driven by the accumulation of growing degree days, as well as cold temperature and day-length for crops sensitive to vernalisation and photoperiod. Crop N uptake is computed through a supply/demand scheme, with soil supply depending on soil nitrate and ammonium concentrations and root length density.

Figure 2 Structure of FarmSim coupled with crop and grassland dynamic models

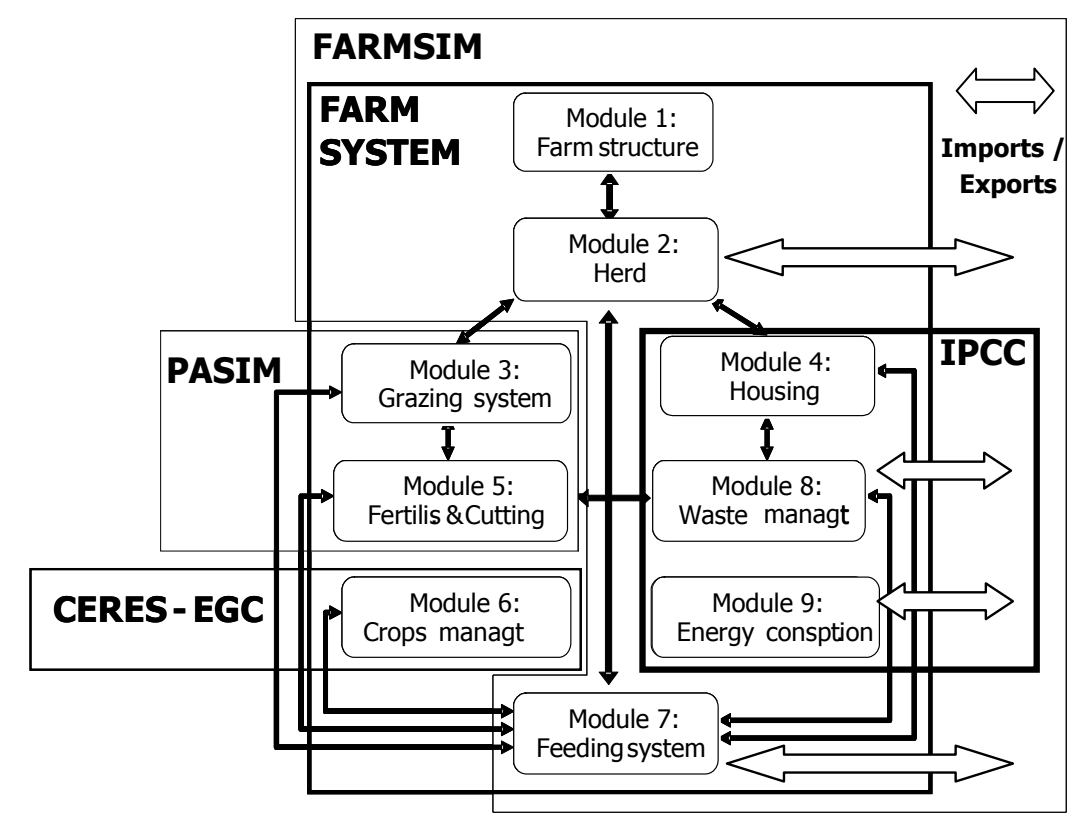

\subsection{From farmer's practices to modelling data}

Coupling PaSim and CERES-EGC allows for mixed crop livestock farming systems with special attention to management regime implemented on grassland and cropland plots. This therefore relies on the translation of farmer's practices into models' variables.

Consequently, for each grassland plot, information is required about time, nature and intensity of removed grass, through indications of cutting or grazing regime, and thus grass yield or stocking density. In addition, $\mathrm{N}$ fertiliser supply both through mineral and organic fertiliser applications is needed in regard to spreading time and rate. Moreover, different grassland types may be distinguished, first from a bio-geographical point of view, and secondly from the species composition and management regime they have: 
even PaSim model is not yet able to simulate such a range. We use PaSim to generate the output from different runs to describe in the best way semi-natural permanent grasslands, intensively managed permanent grasslands, recently sown grass-clover swards, and even unimproved rough grasslands.

For croplands, the required data to describe the different crops involved in the farm cropping system rely on the plant variety and the following practices' data: seeding time and density, time and rate of nitrogen supply through mineral and organic fertiliser applications, harvesting time and crop residues fate. Today, no detail can be accounted for tillage yet.

At the moment, no animal production model is coupled with PaSim and CERES. The emissions associated with animal winterfeeding, livestock housing and manure storage, stay calculated using a spreadsheet module, according to IPCC methodology. In the same way, direct and indirect energy use and emissions associated with the production and providing of imported resources (including transport to the farm) are also accounted for on a special spreadsheet gathering data about fuel, electricity, fertilisers, veterinary products and pesticides, concentrate and others supplies purchased for the farm production. Different databases may be used for these calculations, at the user's convenience.

Figure 3 Grazing and cutting calendar of the grassland fields of a mixed crop livestock farm (Mirecourt farm)

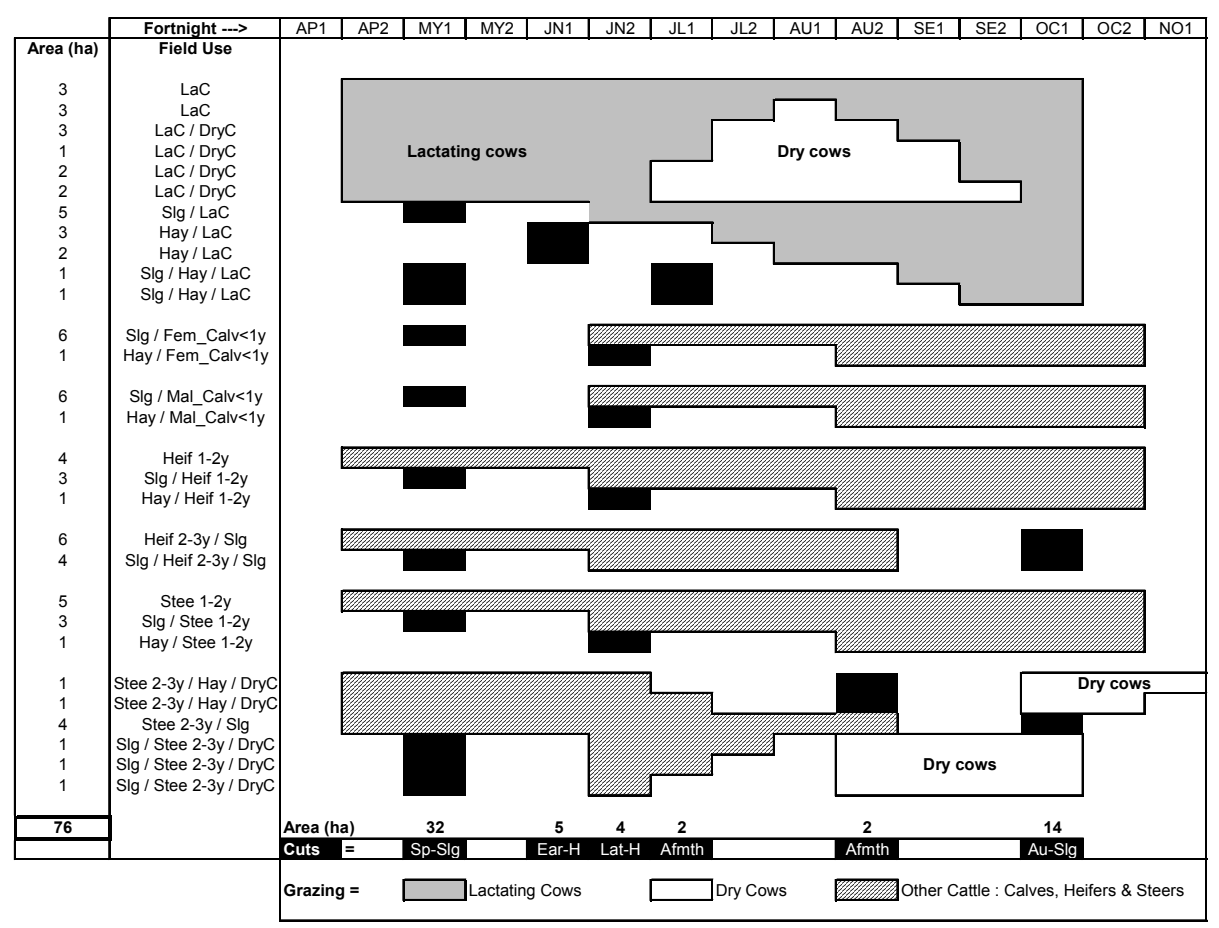

Notes: $\mathrm{Lac}=$ lactating cows, $\mathrm{DryC}=$ dry cows, $\mathrm{Slg}=$ silage, Fem_Calv $=$ female calves, Mal_Cal $=$ male calves, Heif $=$ heifers, Stee $=$ steers; $<1 \mathrm{y}, 1-2 \mathrm{y}, 2-3 \mathrm{y}=$ age classes of animals; $\mathrm{Sp}-\mathrm{Slg}=$ spring silage; Ear-H = early hay; Lat-H = late hay; Afmth = aftermath; Au-Slg = automn silage 
Figure 4 GhG budgets from simulated emissions before (a) and after (b) mitigation options at Mirecourt farm
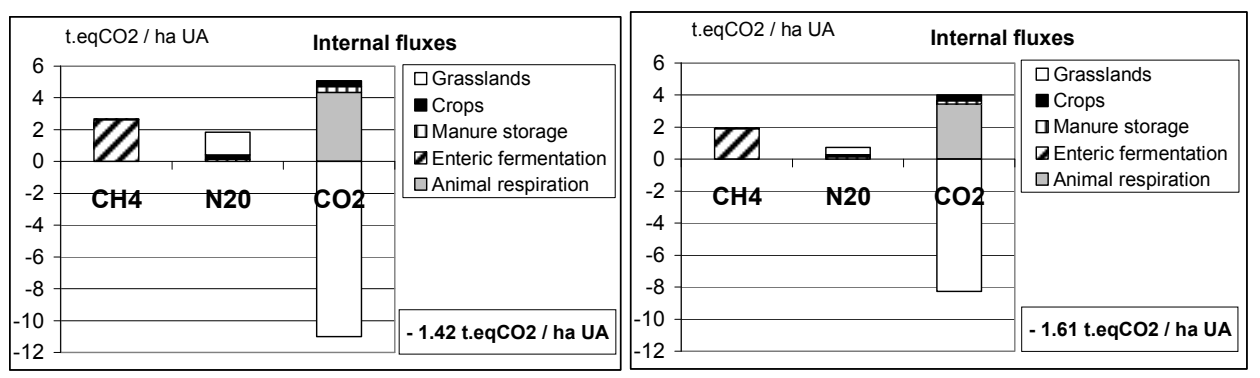

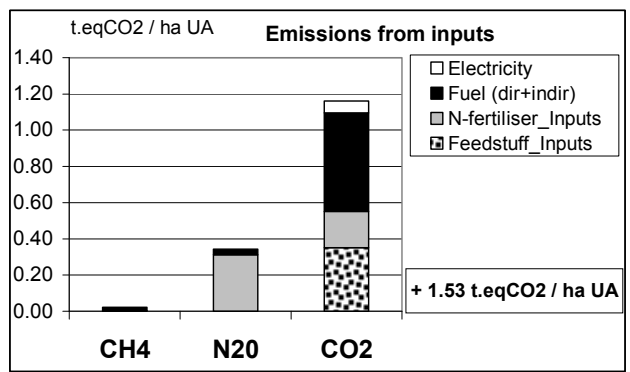

(a)

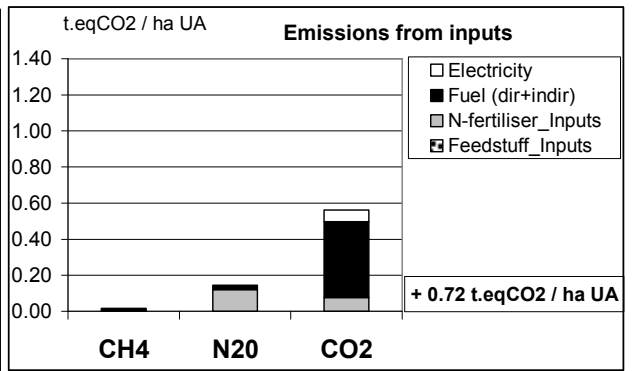

(b)

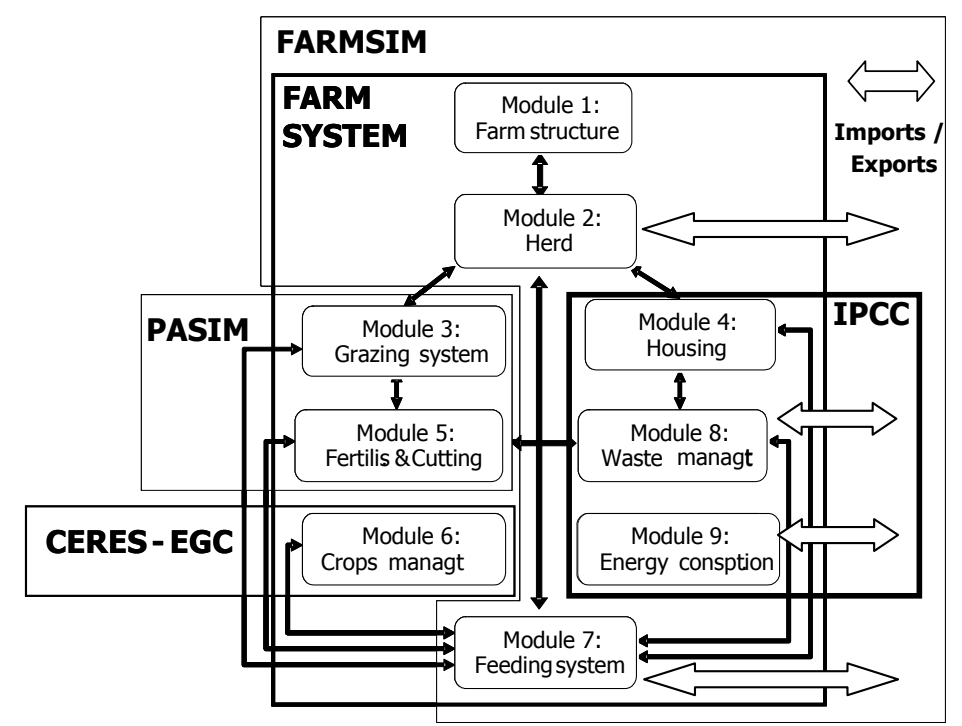

Notes: (a) before mitigation options

(b) with mitigation options

This farm description relies on different likelihood checking, as about fodder and home-grown feeds harvesting collated to animal intake, about collected, stored and spread manure, but also about herd management and batching practices for instance. According to the farm description, one of the main difficulties consists in grassland's analysis to account for the farm operating from a realistic point of view. To this end, we 
use operational field management calendars (Figure 3) from which we identify different grassland types according to their management, collating fertiliser applications, grass removal regimes (grazing or cutting) and for grazing, animal types and stocking density.

The operational calendar allowed the distinction of four main grasslands' types:

1 permanent intensive grasslands exclusively grazed by cows (14 ha)

2 permanent intensive grasslands harvested and grazed by the different animal batches (26 ha)

3 semi-improved grasslands exclusively grazed by heifers and steers ( $9 \mathrm{ha})$

4 semi-improved grasslands harvested and grazed by different animal batches (27 ha), with specific mineral and organic fertilisation practices.

\section{Case study}

\subsection{Mirecourt farm}

The FarmSim new release has been performed for a mixed crop livestock farm located in Lorraine, North-East of France. As a matter of fact, this study case is an ideal type built by the French Livestock Institute, resulting from many real monitored farms and thoroughly informed with data from an INRA experimental farm located in Mirecourt.

The farm structure relies on an agricultural area of 100 ha with a milk quota of 300,000 litres produced by a 48 cow dairy herd. In addition, steers are kept from this dairy herd. Permanent pasture is the major land use with 76 ha. In addition, 24 ha are cultivated with a maize-wheat rotation (including 3 ha of fallow land). Grasslands are grazed from mid April to late October or only during a part of this period: thus 32 ha are harvested as spring grass silage in mid May and 9 ha as hay in June. In addition, some pastures are cut as aftermath during summer or as grass silage in autumn. Mineral nitrogen $(\mathrm{N})$ is supplied from early March to mid summer for most of grazed and cut grasslands. Intensive (40 ha) and semi-improved ( $36 \mathrm{ha}$ ) permanent grasslands are spread on average with 110 and $45 \mathrm{~kg} \mathrm{~N} \mathrm{ha}^{-1}$, respectively. In addition, the intensive grasslands receive 12 tons long term stored manure per ha (i.e., $70 \mathrm{~kg} \mathrm{~N} \mathrm{ha}^{-1}$ ) during autumn. Other grassland types get by mean $60 \mathrm{~kg} \mathrm{~N} \mathrm{ha}^{-1}$ from fresh manure in winter. The grasslands yield from $4.5 \mathrm{t}$ to $6.5 \mathrm{t}$. DM ha ${ }^{-1} \mathrm{yr}^{-1}$ and total roughage stores of about $100 \mathrm{t}, 33 \mathrm{t}$ and $7 \mathrm{t}$. DM as grass silage, hay and aftermath, respectively.

The maize crop yields about $120 \mathrm{t}$. DM as silage used for dairy cows diet from October to April. The winter wheat crop provides about 20 t. DM home-grown feed, and a third (about 35 t. DM) of the straw needs for both heifer's feeding and cattle bedding. Wheat and maize crops are fertilised with 15 tons composted manure, 22 tons fresh manure and $110 \mathrm{~kg}$ and $75 \mathrm{~kg}$ mineral $\mathrm{N} \mathrm{ha}^{-1}$, respectively.

The dairy herd consists of 48 Prim'Holstein cows producing about 6,700 kg milk per year. The replacement rate is $35 \%$ and the heifers calve at 36 months of age. The calving dates run from August to November. All male calves are kept as three years old steers. The feeding system relies on grass utilisation except for indoor lactating cows. From October to April, dairy cows are fed with maize silage $\left(13 \mathrm{~kg} \mathrm{DM} \mathrm{cow}^{-1} \mathrm{~d}^{-1}\right)$ and a little hay and aftermath $\left(2 \mathrm{~kg} \mathrm{DM} \operatorname{cow}^{-1} \mathrm{~d}^{-1}\right)$ as roughage, supplemented by purchased soya-bean cakes and homegrown flattened wheat $\left(2.2 \mathrm{~kg} \mathrm{DM} \operatorname{cow}^{-1} \mathrm{~d}^{-1}\right.$ of each) as 
concentrates. During all the grazing period (six to seven months long), the cows produce milk from grass exclusively. First year calves eat a little hay first, then grass silage and hay just before they are turned out in June. During the grazing period calves intake about $0.5 \mathrm{~kg}$ DM hay per day. They are back in the stable in late October, simultaneously with heifers and steers which are then supplied with $4.5 \mathrm{~kg}$ and $3 \mathrm{~kg} \mathrm{DM}_{\text {animal }}{ }^{-1} \mathrm{~d}^{-1}$ grass silage and straw, respectively. Steers are fattened at grazing and sold from June to September. Roughage balance of this crop livestock farm is rather tense with a global stocking rate of $1.4 \mathrm{LU} \mathrm{ha}^{-1}$ relying on $13 \%$ maize crop, $46 \%$ intensive grasslands and $41 \%$ semi-intensive ones.

A mitigation package for Mirecourt farm has been conceived through a rather strong extensification associated with a feeding self-sufficiency request. This strategy relies on three main options:

1 a strong nitrogen fertilisation reduction $(-50 \%)$ associated with an important decrease of stocking rate to $0.9 \mathrm{LU} \mathrm{ha}^{-1}$ assuming an increase of white clover in pasture composition

2 a complete change of the cropping system (from maize-wheat to field bean-triticale-barley crop rotation) allowing a self-sufficiency for concentrate supplementing hay and grass silage diet

3 a giving up of steer production ( $-36 \mathrm{LU}$ ) associated with an increase of the cows' productive lifetime to keep fewer heifers $(-10 \mathrm{LU})$.

All these options result in a slight decrease of milk yield from $6,800 \mathrm{~kg}$ to $6,400 \mathrm{~kg} \mathrm{cow}^{-1}$ $\mathrm{y}^{-1}$.

\subsection{First simulation results}

Global budgets of GhG emissions [expressed as t. $\mathrm{CO}_{2} \mathrm{ha}^{-1}$ of used agricultural area (UA)] are presented broken down into two components: the net internal fluxes and the inputs related fluxes. The global warming potential (GWP) of Mirecourt farm firstly results from animal respiration $\left(\mathrm{CO}_{2}\right)$ and enteric fermentation $\left(\mathrm{CH}_{4}\right)$ emissions, the latter being $60 \%$ of respiration. These two emissions are directly suited to the cattle number and consequently, a strong animal number decrease results in an important reduction of these components after mitigation: nevertheless, they stay the most important emissions, standing up to $85 \%$ of internal fluxes and $76 \%$ of the total emissions. Before mitigation, $\mathrm{N}_{2} \mathrm{O}$ emissions from grassland fertilisation fill in the third place (15\% of internal fluxes), but the strong reduction of mineral nitrogen makes it far away into the internal fluxes after mitigation.

Considering together internal and external fluxes associated with mineral $\mathrm{N}$ use, the total $\mathrm{N}$ fertiliser contribution falls from $18 \%$ to $9 \%$ of the total calculated emissions. Fuel (direct and indirect) emissions result in the fourth component (about $6 \%$ of the total emissions), both before and after mitigation, whilst $\mathrm{N}_{2} \mathrm{O}$ emissions from cropland $\mathrm{N}$ fertilisation stay at a very low component in the two situations. In addition, the self-produced concentrate supply makes the purchased feedstuff emissions disappear when they stood up to $30 \%$ of the external emissions before mitigation (but only $3 \%$ of the total emissions). 
A special mention must be made about the $\mathrm{C}$ balance and release or sequestration behaviour of grassland and cropland. At the farm scale, the current $\mathrm{C}$ storage rate in the soil is unknown. So, an assumption of net biome productivity (NBP) was done according to literature values (Janssens et al., 2003; Soussana et al., 2004) and considering croplands as moderate sources $\left(+0.46\right.$ t.C- $\left.\mathrm{CO}_{2} \mathrm{ha}^{-1} \mathrm{y}^{-1}\right)$ and grasslands as moderate sinks $\left(-0.335\right.$ t.C- $\left.-\mathrm{CO}_{2} \mathrm{ha}^{-1} \mathrm{y}^{-1}\right)$. So, these two fluxes are calculated in addition with the other ones, making the farm become a net sink $\left(-0.89\right.$ t.eqCO $_{2}$ ha $\left.^{-1} \mathrm{y}^{-1}\right)$ despite a sequestration decrease after mitigation.

\section{Discussion and perspectives}

The whole farm approach is a powerful tool to assess the impact of agricultural practices, even in such complex situations as crop livestock farms. We have demonstrate that a full GhG accounting approach can be developed for these farms and that it allows to estimate consistently GhG budgets, including pre-chain emissions. Considering the pre-chains is clearly important to give to farmers and advisers a better awareness of the consequences of their management decisions for the global environment. Importantly, by simulating the GhG budget of the grasslands with PaSim, we take into account the role of seasonal and inter-annual variability in climate for the GhG emissions at the farm level. According to the croplands, we have now coupled the FarmSim model with CERES-EGC, a generic crop model, allowing then the simulation of field scale GhG balance more efficient than using emission factors for crops practices. This is important to calculate farm budgets over a commitment period in a more realistic way. Another point consists in the units with which the emissions are expressed: if we choose above $\mathrm{kg} \mathrm{eqCO}_{2} \mathrm{ha}^{-1} \mathrm{UA}$, it is then possible to use $\mathrm{kg} \mathrm{eqCO}_{2} \mathrm{LU}^{-1}$ and even $\mathrm{kg}$ eqCO $\mathrm{GJ}^{-1}$ of produce to account for milk, meat and cash crops together.

Nevertheless, this approach still has some weaknesses. First, the assumptions made with the NBP, while helpful, need to be refined by running PaSim and CERES-EGC for a range of initial soil $\mathrm{C}$ contents rather than from an equilibrium. Assumed soil $\mathrm{C}$ contents may in the future be derived from measurements in the farm or from databases on soil $\mathrm{C}$ that now include the land use. Second, the emission coefficients derived from the IPCC methodology can be refined at the farm scale, by making them more flexible, e.g., for the indoors emissions from litter and manure stores.

The FarmSim model is not yet as complete as it would be: a herd management model would largely be welcomed to help check the relationship between forage and manure management systems. A special effort remains to be done about time considering for successive years, e.g., to account for crop sequences and climatic series. In a longer time step, taking account of the background of the fields would allow it to be more explicit and consequently, it would be more efficient to consider realistic transition to mitigation options. In the same time, some practices as supplemented grazing or alternative tillage are not still well considered. Finally, parametrisation remains to be improved (first to describe soils characteristics) and model sensitivity to be tested. 


\section{Conclusions}

While there are clear prospects for mitigation of the individual GhG both from grasslands and croplands, there are clear trade-offs and synergies between the different GhG (and even with other gases as ammoniac or $\mathrm{NO}_{\mathrm{x}}$ ) which are only beginning to be quantified. Increased soil carbon storage associated with increased fertiliser use can be offset by increased nitrous oxide emissions, while changes to reduce methane emissions may cause similar interactions. It is therefore important to assess potential mitigation options for their impact upon all the GhG.

FarmSim, PaSim and CERES-EGC are interesting tools to explore a large range of mitigation options starting from farming actual conditions. A full accounting framework is the only way to give a consistent assessment of the mitigation strategies at the farm scale. A bottom-up approach could induce a better awareness for stakeholders. In addition, since mitigation options have to be implemented by farmers, a farm scale model might give the required insight into the trade-offs between the different GhG despite the great heterogeneity of farming practices.

Implementation of technological measures often requires investments (manure digesters) but these may be cost-effective too in the medium term. Structural adjustments such as decreasing of the animal number or changing crop sequences are expensive too and only cost-effective in terms of mitigation of GhG emissions in the longer term. But some management adjustments are probably cheaper and immediately cost-effective too, such as manure management, crop management and animal feeding strategy. In this way, reducing $\mathrm{N}$ surpluses both at the field scale and at the farm scale allows to reduce $\mathrm{N}$ losses to the environment. As Schils et al. (2006b) noted, there is certainly scope to use $\mathrm{N}$ surplus as a proxy for GhG.

\section{References}

Del Prado, A., Scholefield, D., Chadwick, D., Misselbrook, T., Haygarth, P., Hopkins, A., Dewhurst, R., Davison, P., Lord, E., Turner, M., Aikman, P. and Schröder, J. (2006) 'A modelling framework to identify new integrated dairy production systems', in Lloveras, J. et al. (Eds.): EGF $21^{\text {st }}$ General Meeting. Grassland Science in Europe: Sustainable Grassland Productivity, pp.766-768, Badajoz.

EEA (2007) 'Annual European community greenhouse gas inventory 1990-2005 and inventory report 2007', EEA Technical Report No. 7, European Environment Agency, Copenhagen.

Freibauer, A. (2003) 'Regionalised inventory of biogenic greenhouse gas emissions from European agriculture', European Journal Agronomy, Vol. 19, No. 2, pp.135-160.

Gabrielle, B., Denoroy, P., Gosse, G., Justes, E. and Andersen, M.N. (1998) 'Development and evaluation of a CERES type model for winter oilseed rape', Field Crops Research, Vol. 57, No. 1, pp.95-111.

IPCC (1997) 'Revised 1996 IPCC guidelines for national greenhouse gas inventories', Intergovernmental Panel on Climate Change, Geneva, Switzerland.

Janssens, I.A., Freibauer, A., Ciais, P., Smith, P., Nabuurs, G.J., Folberth, G., Schlamadinger, B., Hutjes, R.W.A., Ceulemans, R., Schulze, E.D., Valentini, R., Dolman, A.J. (2003) 'Europe's terrestrial biosphere absorbs 7 to $12 \%$ of anthropogenic $\mathrm{CO}_{2}$ emissions', Science, Vol. 300 , No. 5625, pp.1538-1542.

Jones, C.A. and Kiniry, J.R. (1986) CERES-Maize: A Simulation of Maize Growth and Development, Texas A\&M University Press, Temple. 
Molina, J.A.E., Clapp, C.E., Schaffer, M.J., Chichester, F.W. and Larson, W.E. (1983) 'NCSOIL, a model of nitrogen and carbon transformations in soil: description, calibration and behaviour', Soil Science Society American Journal, Vol. 47, No. 1, pp.85-91.

Olesen, J.E., Schelde, K., Weiske, A., Weijsberg, M.R., Asman, W.A.H. and Djurhuus, J. (2006) 'Modelling GhG emisions from European conventional and organic dairy farms', Agriculture Ecosystems \& Environment, Vol. 112, Nos. 2-3, pp.207-220.

Riedo, M., Grub, A., Rosset, M. and Fuhrer, J. (1998) 'A pasture simulation model for dry matter production, and fluxes of carbon, nitrogen, water and energy', Ecological Modelling, Vol. 105, Nos. 2-3, pp.141-183.

Riedo, M., Gyalistras, D. and Fuhrer, J. (2000) 'Net primary production and carbon stocks in differently managed grasslands: simulation of site-specific sensitivity to an increase in atmospheric $\mathrm{CO} 2$ and to climate change', Ecological Modelling, Vol. 134, Nos. 2-3, pp.207-227.

Salètes, S., Fiorelli, J.L., Vuichard, N., Cambou, J., Olesen, J.E., Hacala, S., Sutton, M., Fuhrer, J. and Soussana, J.F. (2004) 'GhG balance of cattle breeding farms and assessment of mitigation options', in Kaltschmitt, M. and Weiske, A. (Eds.): GhG Emissions from Agriculture. Mitigation Options and Strategies, pp.203-208, Leipzig, Germany.

Schils, R.L.M., Olesen, E.O., del Prado, A. and Soussana, J.F. (2006a) 'A farm level approach for mitigating GhG emissions from ruminant livestock systems', 12th Ramiran International Conference,Technology for Recycling of Manure and Organic Residues in a Whole-Farm Perspective, DIAS Report, Plant Production, Vol. 122, pp.17-24.

Schils, R.L.M., Verhagen, A., Aarts, H.F.M. and Sebek, L.B.J. (2005) 'A farm level approach to define successful mitigation strategies for GhG emissions from ruminant livestock systems', Nutrient Cycling in Agroecosystems, Vol. 71, No. 2, pp.163-175.

Schils, R.L.M., Verhagen, A., Aarts, H.F.M., Kuikman, P.J. and Sebek, L.B.J. (2006b) 'Effect of improved nitrogen management on greenhouse gas emissions from intensive dairy systems in the Netherlands', Global Change Biology, Vol. 12, No. 2, pp.382-391.

Schmid, M., Neftel, A., Riedo, M. and Fuhrer, J. (2001) 'Process-based modelling of nitrous oxide emissions from different nitrogen sources in mown grassland', Nutrient Cycling in Agroecosystems, Vol. 60, Nos. 1-3, pp.177-187.

Smith, P. (2004) 'Carbon sequestration in croplands: the potential in Europe and the global context', European Journal of Agronomy, Vol. 20, No. 3, pp.229-236.

Soussana, J.F., Fuhrer, J., Jones, M. and Van Amstel, A. (2007) 'The greenhouse gas balance of grasslands in Europe', Agriculture Ecosystems \& Environment, Vol. 121, Nos. 1-2, pp.1-192.

Soussana, J.F., Loiseau, P., Vuichard, N., Ceschia, E., Balesdent, J., Chevallier, T. and Arrouays, D. (2004) 'Carbon cycling and sequestration opportunities in temperate grasslands', Soil Use Management, Vol. 20, No. 2, pp.219-230.

Thornley, J.H.M. (1998) Grassland Dynamics: An Ecosystem Simulation Model, Oxon, CAB International, Wallingford, UK, 241p.

Van Alem, G.A.A. and Van Scheppingen, A.T.J. (1993) 'The development of a farm budgeting program for dairy farms', in Annevelink, E., Oving, R.K. and Vos, H.W. (Eds,): Proc. XXV CIOSTA-CIGR V, pp.326-331, Wageningen.

Vuichard, N., Soussana, J-F., Ciais, P., Viovy, N., Ammann, C., Calanca, P.L., Clifton-Brown, J., Fuhrer, J., Jones, M. and Martin, C. (2007) 'Estimating the greenhouse gas fluxes of European grasslands with a process-based model: 1 . Model evaluation from in situ measurements', Global Biogeochemical Cycles, Vol. 21, 13p., GB1004, doi:10.1029/2005GB002611.

Weiske, A., Vabitsch, A., Olesen, J.E., Schelde, K., Michel, J., Friedrich, R. and Kaltschmitt, M. (2006) 'Mitigation of greenhouse gas emissions in European conventional and organic dairy farming', Agriculture Ecosystems \& Environment, Vol. 112, Nos. 2-3, pp.221-232.

Wheeler, D.M., Ledgard, S.F. and DeKlein, C.A.M. (2008) 'Using the OVERSEER ${ }^{\circledR}$ nutrient budget model to estimate on-farm greenhouse gas emissions', Australian Journal of Experimental Agriculture, Vol. 48, No. 2, pp.99-103. 